\title{
Sympathy, Community, and Promising: Adam Smith's Case for Reviving Moral Consideration
}

\author{
Mark K. Moller†
}

\begin{abstract}
Consider whether courts should enforce the following promises:
\end{abstract}

1. Rich Aunt Tillie gives her nephew Charley a $\$ 1,000$ promissory note payable when he turns five. After Charley sets fire to Tillie's favorite couch, however, she refuses to honor the note.

2. Jane and Susan, a long-time lesbian couple, have lived together for fifteen years. Jane, terminally ill, promises Susan all that she owns upon her death. When she dies, the executors of Jane's estate, her estranged family, refuse to honor the promise.

3. Three brothers are separated in their early teens. One brother, much later in life, wins the lottery and, thanks to the popular television program Unsolved Mysteries, relocates his brothers and promises each $\$ 1$ million. But, when he discovers that both brothers have turned into characters of ill repute, he refuses to pay.

Long ago, English common law courts articulated an embryonic version of the doctrine of consideration that might have allowed enforcement of the above promises. Working in a legal atmosphere that wedded common law reasoning to ethical theory, some early common law courts held that love and affection should count as valid consideration for a promise. ${ }^{1}$ In other words, these

† B.A. 1994, Duke University; J.D. Candidate 1999, The University of Chicago.

1 See, for example, Lord Grey's Case, Bodl, MS Rawl, C112, F292 (1567) (opinion by Dyer) (noting that "the benefit of my friend is to my benefit and case also"), cited and quoted in Kevin M. Teeven, A History of the Anglo-American Common Law of Contract 59 n 103 (Greenwood 1990); Dutton v Pool, 1 Ventr 318, 86 Eng Rep 205, 205 (KB 1678) (arguably upholding a promise based on the theory that love and affection count as consideration), cited in A.W.B. Simpson, A History of the Common Law of Contract 479 (Oxford 1975); Hawkes $v$ Saunders, 1 Cowpr 289, 98 Eng Rep 1091, 1091 (KB 1782) (holding that "[w] here a man is under a moral obligation ... the honesty and rectititude of the thing is a consideration"), cited in Friedrich Kessler, Grant Gilmore, and Anthony Kronman, eds, Contracts: Cases and Materials 510 (Little, Brown 3d ed 1986). For a discussion of the in- 
courts held that a donative promise, absent any bargain or promise in exchange, became enforceable in "affective" relationships. Despite the attempts of the great eighteenth century jurist Lord Mansfield to stamp this approach permanently into contract law, consideration based on love and friendship, a species of "moral consideration," has passed into near desuetude. ${ }^{2}$

Through a series of classic cases, culminating in Dougherty $v$ Salt ${ }^{3}$ courts reached a consensus that a donative promise in a family relationship was "the voluntary and unenforceable promise of an executory gift." Yet, even after Dougherty, courts on rare occasions have enforced donative promises supported by love and affection. For instance, in In re Cirillo's Estate, ${ }^{5}$ a New York court upheld a father's promise to support an acknowledged illegitimate child, despite the fact that the father was under no legal obligation to support the child. ${ }^{6}$ One year later, another New York court explained that the natural, and moral, obligation between father and child provided the consideration for an otherwise gratuitous promise. ${ }^{7}$ A few other cases have taken similar approaches. ${ }^{8}$ Nonetheless, such cases remain odd exceptions to

fluence of ethical theory, especially neo-Aristotelian ethical theory, on the early development of the doctrine of consideration and other modern contract doctrines, see generally James Gordley, The Philosophical Origins of Modern Contract Doctrine (Oxford 1991).

${ }^{2}$ See note 75 for sources discussing Mansfield and moral consideration. For a synopsis of the modern rule on moral consideration, see Richard A. Lord, 3 Williston on Contracts $\$ 7: 16$ at 317-30 (Law Co-op 4th ed 1992); 4 id $\S 8: 12$ at 242-62.

"Moral consideration" is used in this Comment in the broadest sense articulated by Lord Mansfield in Hawkes: "[W]here a man is under a moral obligation . . . and promises, the honesty and rectititude of the thing is a consideration." 98 Eng Rep at 1091. The Hawkes rule, read literally, encompassed the use of love and affection as consideration. See, for example, Lawrence v Oglesby, $178 \mathrm{III} 122,52 \mathrm{NE} 945,945$ (1899) (holding that the promise of father to daughter is supported by moral consideration under the Hawkes rule). Later American cases have referred to moral consideration in a narrower sense, to uphold a subsequent promise meant to ensure compensation for a past benefit. See, for example, Webb v McGowin, 27 Ala App 82, $168 \mathrm{~S}$ 196, 198 (1935) (holding that moral obligation is a "sufficient consideration to support a subsequent promise to pay where the promisor has received a material benefit"). This Comment argues exclusively for a revival of the doctrine that love and affection should count as consideration, a doctrine that is a species of the moral consideration theory articulated in Hawkes.

3227 NY 200, $125 \mathrm{NE} 94$ (1919).

4 Dougherty, $125 \mathrm{NE}$ at 95 . In England, moral consideration ceased to be an operative doctrine after Eastwood $v$ Kenyon, 113 Eng Rep 482 (QB 1840); in America, a number of cases prior to Dougherty struck down donative promises for lack of consideration. See, for example, Mills v Wyman, 20 Mass (3 Pick) 207 (1825); Fischer v Union Trust Co, 138 Mich $612,101 \mathrm{NW} 852$ (1904). Dougherty is the last and most famous in this series.

- 114 NYS2d 799 (Sur Ct 1952).

- Id at 801.

7 See Duncan v Duncan, 123 NYS2d 541, 542 (Sup Ct 1953), revd on other grounds, Duncan v Clarke, 308 NY 282, 125 NE2d 569 (1955).

${ }^{*}$ See, for example, United States $v$ Cook, 257 US 523, 527 (1922) ("There was the moral consideration which properly induced the recognition of an.honorable obligation and 
the well-established rule that love and affection do not render donative promises enforceable.

Modern commentators tend to agree that courts should not enforce donative promises, and they support this claim with normative arguments about affective relationships. Three reasons for nonenforcement are commonly advanced. First, enforcement opponents claim that donative promises, arising as they do in affective relationships, are likely to be impulsive and illconsidered. ${ }^{9}$ The contract law requirement of mutual assent thus argues against their enforcement. Second, opponents argue that courts are not institutionally competent to objectively evaluate and protect expectations that arise in the world of love and friendship. ${ }^{10}$ Expectations among family or friends about obligations or commitments are emotional and value-laden and therefore inherently subjective; judges cannot reason about them without imposing their own subjective value judgments on promisors and promisees. ${ }^{11}$ Finally, opponents argue that enforcement devalues the special nature of commitments of love and friendship by sending a message that these promises are no different from hard-headed commercial promises. ${ }^{12}$

To modern ears, such claims sound plausible. Nevertheless, they are denied by one of the most subtle and wide ranging theorists on the relationship between emotion and action, Adam Smith. ${ }^{13}$ In The Theory of Moral Sentiments, Smith's treatise on

turned an unenforceable equity into a binding and effective provision."); Lawrence, $52 \mathrm{NE}$ at 946 (noting that a son's promise to honor his dying father's gratuitous promise to his sister is made enforceable by moral consideration). See generally Lord, 4 Williston on Contracts $\S 8: 12$ at 245-47 nn 1-2 (cited in note 2) (listing cases in which moral consideration was recognized as consideration).

${ }^{9}$ See Melvin A. Eisenberg, Donative Promises, 47 U Chi L Rev 1, 17 (1979); Kessler, Gilmore, and Kronman, eds, Contracts: Cases and Materials at 471 (cited in note 1) (noting that donative promises are "often made impulsively and with little reflection").

${ }^{10}$ See Melvin A. Eisenberg, The World of Contract and the World of Gift, $85 \mathrm{Cal} \mathrm{L} \mathrm{Rev}$ 821, 847 (1997) (arguing that the "impersonal organs of the state" are an inappropriate means to enforce commitments "driven by affective considerations like love, affection, friendship, gratitude, and comradeship"). See also Lord, 4 Williston on Contracts § 8:12 at 249-50 (cited in note 2).

" See Lord, 4 Williston on Contracts $\S 8: 12$ at 249-50 (cited in note 2) (stating that if moral obligation made promises binding, courts' ad hoc value judgments would undermine the uniformity and predictability of contract law).

${ }^{22}$ See Eisenberg, $85 \mathrm{Cal} L \mathrm{Rev}$ at 848 (cited in note 10) ("[M]aking simple, affective donative promises enforceable would have the effect of commodifying the gift relationship."); Roberto Mangabeira Unger, The Critical Legal Studies Movement, 96 Harv L Rev 561,622 (1983) (noting that contract law singles out the realm of love and affection for special treatment, based on the assumption that family and friendship neither "need much law nor are capable of tolerating it").

${ }^{13}$ See, for example, Martha C. Nussbaum, Flawed Foundations: The Philosophical Critique of (a Particular Type of) Economics, 64 U Chi L Rev 1197, 1211 (1997) ("Adam 
reason and emotion, he argues that our emotions are cognitive, that they involve evaluative thought, or, as he calls it, "sympathetic" reasoning. ${ }^{14}$ While Smith's terminology may sound alien to the ears of modern lawyers, Smith's sympathetic reasoning is, as some commentators have recently noted, similar to analogical reasoning. ${ }^{15}$ According to Smith, it is this process that imparts rationality both to the act of promising within an affective relationship and to judicial reasoning about promise enforcement within affective relationships.

Building on his analysis of emotion and reason, Smith argues in his Lectures on Jurisprudence ${ }^{16}$ that gratuitous promises between family members create expectations worthy of judicial enforcement. To the extent that the modern case against donative promise enforcement rests on normative assumptions about emotions and reason, supporters of the modern rule cannot ignore Smith's rigorous analysis. This Comment concludes, with Smith, that courts should once again enforce promises in "moral consideration" contexts; its three Parts present each of Smith's arguments in turn.

Part I of this Comment outlines Smith's argument that parties involved in long-term, habitual relationships do not act impulsively toward one another, but rather use emotions cognitively and deliberatively to reach a shared set of expectations about commitments and obligations. Part II argues that promising signals the shared expectations in habitual relationships to courts, thereby allowing courts to recognize objectively when such expectations have been violated and enforce them. Finally, Part III concludes that legal rules convey a message about what a political community agrees to be ethical, and that failure to enforce

Smith is one of the greatest thinkers about the relationship between emotion and action, and he seems to have thought that this inquiry (both predictive and normative) was an important part of thinking about the economy and public policy."); Robin L. West, Taking Preferences Seriously, 64 Tulane L Rev 659 (1990) (discussing Smith's theory of "sympathetic judgment" and its relevance to debates over judicial reasoning about private preferences).

16 Adam Smith, The Theory of Moral Sentiments 16, 319-20 (Liberty Classics 1982) (D.D. Raphael and A.L. Macfie, eds). See also Dan M. Kahan and Martha C. Nussbaum, Two Conceptions of Emotion in Criminal Law, 96 Colum L Rev 269, 287-88 (1996) (noting that Smith presumes that our actions involve "evaluative thought").

${ }^{15}$ See Note, Sympathy as a Legal Structure, 105 Harv L Rev 1961, 1964 (1992) (claiming that "[a]nalogy is the operative function" in Smith's account of sympathy). For further discussion of the relation between sympathetic and analogic reasoning, see note 25.

${ }^{16}$ Adam Smith, Lectures on Jurisprudence (Liberty Classics 1982) (R.L. Meek, D.D. Raphael, and P.G. Stein, eds). 
donative promises expresses an ethical undervaluation of commitments in close, habitual relationships.

\section{THE SCOPE OF RATIONAL DELIBERATION IN AFFECTIVE RELATIONSHIPS}

\section{A. Sympathetic Reasoning: Using Emotions to Deliberate}

The most basic argument against enforcing donative promises is that they are likely to be irrational and ill-considered. As Professor Melvin Eisenberg notes, promissory obligations are predicated on the promisor's deliberative exercise of his will. ${ }^{17}$ Courts seek to ensure that contractual liability is imposed only where the promisor has fully deliberated before making a promissory commitment. Yet, promisors who are emotionally involved with the promisee are likely to make uncalculated acts of generosity. ${ }^{18}$ Because emotionally involved promisors do not deliberate but instead act impulsively, they do not act with the rationality and volition necessary to create a legally enforceable promissory obligation.

Smith takes the opposite position and argues that our emotions are cognitive; in other words, as Professors Martha Nussbaum and Dan Kahan explain, our emotions "involve evaluative thought."19 Thus, intimate relationships in which emotion figures prominently are not necessarily characterized by arbitrariness and irrationality. Indeed, Smith argues that long-term habitual relationships are the most deliberative human relationships of all. $^{20}$

The faculty of sympathy stands at the center of Smith's account of emotional deliberation, and it forms the basis for Smith's argument that affective commitments are likely to be fully considered. Sympathy, as Smith uses the word, is not empathy or intuition; it is an exercise of the imagination to step into another's position and attempt to feel what he feels. ${ }^{21}$ This imaginative leap

${ }^{17}$ Eisenberg, $47 \mathrm{U}$ Chi L Rev at 5 (cited in note 9).

${ }^{18}$ See id.

${ }^{19}$ Kahan and Nussbaum, 96 Colum L Rev at 287 (cited in note 14). Smith draws on Aristotle and the Roman Stoics for his cognitive account of the emotions. See Nussbaum, $64 \mathrm{U}$ Chi L Rev at 1197 (cited in note 13) (noting that Smith's "complex cognitive analyses of emotion" are "based on Aristotle and the Stoics"). See also Cicero, On Duties 40 (Cambridge 1991) (M.T. Griffin and E.M. Atkins, eds) (E.M. Atkins, trans) ("Reason . . commands, and impulse obeys.").

${ }^{20}$ See text accompanying notes $44-48$.

${ }^{21}$ Smith, Moral Sentiments at 9 (cited in note 14). As Smith elaborates:

As we have no immediate experience of what other men feel, we can form no idea of the manner in which they are affected, but by conceiving what we ourselves should feel in the like situation.... [m] is by the imagination only that we can form any con- 
allows an individual to make judgments about the propriety or merit of another's conduct. ${ }^{22}$ To see how this works, consider the use of sympathy to evaluate the propriety of another's emotional expression. $O$ observes $A$ manifesting grief by weeping. $O$ cannot deliberate about the propriety of A's emotional expression until he places himself in A's situation. O imagines himself facing the very circumstances faced by $A$, and then compares the grief he actually feels with the grief he observes A displaying. ${ }^{23}$ If A manifests more or less grief than $O$ imagines when standing in A's shoes, then $O$ disapproves of A's grief and judges it improper. ${ }^{24}$ In this way, says Smith, our emotions are the yardstick by which we measure propriety, and sympathy is the heuristic device by which we bring this yardstick to bear. ${ }^{25}$

Nussbaum emphasizes that, for Smith, sympathy is not simply a heuristic device to perceive independently existing "ethical maxims."26 Sympathy defines what is proper or ethical; the sympathetic stance is the ethical stance. ${ }^{27}$ For Smith, human beings are social beings, endowed with a natural faculty of sympathy. We act ethically when we fulfill our social natures-in other

ception of what are his sensations. . . . by representing to us what would be our own, if we were in his case.

Smith does at times use sympathy in its usual sense to mean empathy or fellow-feeling in another. See id at 10 ("Sympathy . . . may now . . . be made use of to denote our fellowfeeling."). At other times, sympathy is used to connote "that imaginary change of situation." Id at 21. This Comment uses sympathy to denote Smith's latter sense of the word-a neutral imaginative device to reason about other's emotions.

${ }^{22}$ See id at 16-23 (describing the manner in which sympathy is used to judge propriety and impropriety).

${ }^{23}$ Smith makes the strong claim that sympathy "excites some degree of the same emotion" within us in actuality. Id at 9 .

26 See id at 18-19 "If, upon bringing the case home to our own breast, we find that the sentiments which it gives occasion to, coincide and tally with our own, we necessarily approve of them ... ; if otherwise, we necessarily disapprove of them, as extravagant and out of proportion.").

${ }^{25}$ Sympathy has been called a form of analogical reasoning by some legal commentators. See Note, 105 Harv L Rev at 1964 (cited in note 15). While there is a certain similarity, analogical reasoning, in fact, is subtly different. In analogical reasoning, $O$ would compare A's situation to a different, but comparable, situation that $O$ actually encountered. In sympathetic reasoning, $O$ imagines that he is in A's actual situation whether or not he has ever experienced that situation or anything like it, and then compares his emotional reaction to this imagined situation to A's actual reaction. Sympathetic reasoning involves imagination to an extent that analogical reasoning does not; indeed, analogical reasoning involves comparison rather than actual imagination. In many cases, though, the difference may be more formal than substantive. But where A's situation is unique or alien to $O$, sympathetic evaluation, because it is more direct, is less prone to bias or distortion than analogical evaluation. See Smith, Moral Sentiments at 317 (cited in note 14).

${ }^{25}$ Martha C. Nussbaum, Love's Knowledge: Essays on Philosophy and Literature 345 (Oxford 1990).

${ }^{27}$ See id. 
words, when we act in accordance with mutual sympathy. As Nussbaum says, "[m]orality [for Smith] essentially involves thinking of oneself as one person among others, bound by ties of friendship and sympathy to those others. ${ }^{228}$ Actions that violate mutual sympathy, that others cannot sympathize with, are unethical.

Mutual sympathy is not a just normative prescription, however. It is a human urge. ${ }^{29} \mathrm{We}$ are not governed only by selfinterested passions; as social beings we are endowed with a separate passion suitable to the social side of our natures, a passion to be bound emotively to others. ${ }^{30}$ Yet, because this passion is not self-interested, we are not interested only in mutual sympathy toward ourselves. Rather, mutual sympathy is akin to an interest in a principle. We are offended by its violation in general, and not only toward ourselves. ${ }^{31}$ Thus, for Smith, parties in an affective

28 Id.

${ }^{2}$ See Smith, Moral Sentiments at 110-11 (cited in note 14) (explaining that if a solitary man were brought for the first time into society, his desire for mutual sympathy would cause him to give attention to the shape of his character, and would become the first cause of the subsequent shape of his emotions and desires).

This empirical claim is hardly novel. Aristotle viewed sociability as an inherent quality of human beings. See Aristotle, Nicomachean Ethics 1097b8-15 (Hackett 1985) (Terence Irwin, trans) (" $[$ W] hat we count as self-sufficient is not what suffices for a solitary person by himself, living an isolated life, but what suffices also for parents, children, wife, and in general for friends and fellow-citizens, since a human being is a naturally political [animal].") (alteration in original).

${ }^{30}$ See Smith, Moral Sentiments at 13 (cited in note 14) (" $[N]$ othing pleases us more than to observe in other men a fellow-feeling with all the emotions of our own breast.").

${ }^{31}$ As Smith elaborates:

Sympathy [ ] cannot, in any sense, be regarded as a selfish principle. When I sympathize with your sorrow or your indignation, it may be pretended, indeed, that my emotion is founded in self-love, because it arises from bringing your case home to myself, from putting myself in your situation, and thence conceiving what I should feel in the like circumstances. But though sympathy is very properly said to arise from an imaginary change of situations with the person principally concerned, yet this imaginary change is not supposed to happen to me in my own person and character, but in that of the person with whom I sympathize. When I condole with you for the loss of your only son, in order to enter into your grief ... I consider what I should suffer if I was really you, and I not only change circumstances with you, but I change persons and characters. My grief, therefore, is entirely upon your account, and not in the least upon my own. It is not, therefore, in the least selfish. How can that be regarded as a selfish passion, which does not arise even from the imagination of any thing that has befallen, or that relates to myself, in my own proper person and character, but which is entirely occupied about what relates to you?

Id at 317.

Our ability to deliberate about mutual sympathy depends on the use of sympathy. Sympathy, however, is not self-interested; hence, our deliberation about mutual sympathy is general and not self-centered. Smith makes this point clear when discussing "commutative justice." See id at 78-85, 269. One practices commutative justice when one "abstain[s] from doing [another] any positive harm ... either in his person, or in his estate." Id at 269. 
relationship can use sympathy to deliberate about expectations, and they are driven to do so by their sociable passions.

B. Imaginative Distance, Community Bias, and Bounded

Commonality: The Limits of Sympathetic Reasoning

While Smith argues that deliberation and emotion are not, as opponents of donative promise enforcement claim, incompatible, he recognizes that sympathetic reasoning, like all forms of rationality, is sometimes bounded. Smith identifies three limitations on sympathetic reasoning: imaginative distance, community bias, and bounded commonality. Donative promises have the strongest claim to enforcement in those relationships that are least subject to these barriers to sympathetic rationality.

\section{Imaginative distance.}

Physical distance limits an observer's ability to have "fellow feeling" with an actor. $O$ only imaginatively enters A's position, and $\mathrm{O}$, in the back of his mind, knows this. A's situation, in most cases, does not affect $\mathrm{O}$ as directly as it does A. Because of this imaginative distance, $\mathrm{O}$ is never fully able to feel as much emotion as A feels. Thus, says Smith, "[ $t]$ he emotions of the spectator[s] will . . . be very apt to fall short of the violence of what is felt by the sufferer[s]. . . The thought of their own safety, the thought that they themselves are not really the sufferers, continually intrudes itself upon them. ${ }^{32}$

As a result, A's passions will often seem excessive to $O$, unless A makes an effort to "bring down" the passion to the level $O$ can enter into. The more directly A's situation affects $\mathrm{O}$, the less that distance will limit O's evaluation.

\section{Community bias.}

Sympathetic reasoning is further limited by community bias. Driven by their attachment to the principle of mutual sympathy, humans moderate their own behavior to allow other spectators to

When A causes harm to B's person or estate, A has failed to treat B as an object of sympathy; this is the most extreme, most fundamental violation of mutual sympathy. The desire to punish others who cause intentional harm, implies Smith, is universal in occurrence and strength across individuals and communities. See id at 88 (noting that the crimes of the guilty create a "natural indignation" in observers); id at 86 (claiming that the sense of justice is "implanted in the human breast" by the "peculiar and darling care of Nature"). Because we are offended by violations of mutual sympathy in general, we treat all violations of commutative justice similarly.

${ }^{32}$ Id at 21-22. See also Note, 105 Harv L Rev at 1963 (cited in note 15) ("The reality of one's status as spectator continually interferes with the sympathetic interaction."). 
bridge imaginative distance and sympathetically enter into their own emotions. ${ }^{33}$ However, this process of moderation is conducted within a community of sympathy, and the distribution of evaluative judgments in the community determines the outcome of moderation.

How does this happen? Familiar with the position of the evaluative spectator, $\mathrm{O}$ uses sympathy toward those who observe and evaluate him. By assuming the spectator's place, $\mathrm{O}$ imagines the spectator's sense of distance; $\mathrm{O}$ moderates his own passions to the extent that he, as an "imaginary spectator," can identify with his own passions. The idea of an "imaginary spectator" gives $\mathrm{O}$ a means of critically distancing himself from his emotions. ${ }^{34}$

O's final idea of an imaginary spectator, however, is not based on any particular spectator. When imagining how the imaginary spectator would evaluate him, $\mathrm{O}$ draws upon his interaction with a number of evaluative spectators within his community. The imaginary spectator is thus a generalization drawn from O's particular experiences of being evaluated..$^{35}$ Yet, in a community of one hundred people, some may have a greater imaginative capacity to "enter into" O's passion than others; but it is the general ability to "enter into" O's passion that defines the idea of the imaginary spectator. Thus, the influence of the imaginary spectator imparts consistency to a community's ability to measure propriety, because individual evaluations cluster around the generality. But different communities may cluster around different generalities, creating substantial deviations in judgment among different communities. ${ }^{36}$ As a result, sympathetic delibera-

${ }^{3}$ Smith, Moral Sentiments at 22 (cited in note 14):

The person principally concerned ... desires a more complete sympathy. He longs for that relief which nothing can afford him but the entire concord of the affections of the spectators with his own.... But he can only hope to obtain this by lowering his passion to that pitch, in which the spectators are capable of going along with him.

${ }^{34}$ Id at 112:

[O]ur first moral criticisms are exercised upon the characters and conduct of other people; and we are all very forward to observe how each of these affects us. But we soon learn, that other people are equally frank with regard to our own... We begin, upon this account, to examine our own passions and conduct .... We suppose ourselves the spectators of our own behaviour, and endeavour to imagine what effect it would, in this light, produce upon us.

${ }^{35}$ Thus, Smith says, "The man who is conscious to himself that he has exactly observed those measures of conduct which experience informs him are generally agreeable, reflects with satisfaction on the propriety of his own behaviour." Id at 116 (emphasis added). See also id at 247 (repeating that the imaginary spectator is formed from particular interactions and observations).

${ }^{36}$ See id at 204 :

The different situations of different ages and countries are apt ... to give different 
tion may be biased, as Professor Stanley Fish claims, by the influence of the "interpretive community" in which it is conducted. ${ }^{37}$

\section{Bounded commonality.}

Certain common emotional experiences are triggered in response to particular circumstances that are rarely the same for each individual. Imaginative distance is absolute in these cases, because the experience is uniquely individual, beyond sympathy's power of perception. Romantic love is a chief example. When considered across a spectrum of individuals, imaginative distance arises in response to arbitrary particularities. ${ }^{38}$ In Smith's view, Nussbaum writes, "it retains always an element of the surd, the mysterious, the impenetrably arbitrary. ${ }^{39}$ Thus, says Smith, a spectator can use sympathy toward emotions incident to being in love (happiness at finding love reciprocated or disappointment in rejection) but cannot imagine the love itself. ${ }^{40}$

It is the emotions in which bounded commonality plays a role that are truly subjective and arbitrary. Expectations that arise in the context of these emotions, implies Smith, are indeed "cognitively impenetrable," in the words of Professor Robin West." They are the only emotions that deserve this classification.

\section{Sympathetic Reasoning in Communities of Habitual Sympathy}

Smith claims that, of all intimate relationships, those characterized by habitual interaction are least subject to the limitations on sympathetic rationality. To see this, consider interac-

characters to the generality of those who live in them, and their sentiments concerning the particular degree of each quality, that is either blamable or praise-worthy, vary, according to that degree which is usual in their own country, and in their own times.

${ }^{37}$ See Stanley Fish, Fish v. Fiss, in Sanford Levinson and Steven Mailloux, eds, Interpreting Law and Literature: A Hermeneutic Reader 251, 259-62 (Northwestern 1988). On this point, see also Note, 105 Harv L Rev at 1965 (cited in note 15) (noting that sympathy "marginalizes non-common perspectives and insures that they remain non-common").

${ }^{33}$ Smith, Moral Sentiments at 31 (cited in note 14):

Our imagination not having run in the same channel with that of the lover, we cannot enter into the eagerness of his emotions. ... [W]e never think of ourselves bound to conceive a passion of the same kind, and for the same person for whom he has conceived it.

See also Nussbaum, Love's Knowledge at 338-47 (cited in note 26).

${ }^{39}$ Nussbaum, Love's Knowledge at 342 (cited in note 26).

${ }^{40} \mathrm{Smith}$, Moral Sentiments at 32 (cited in note 14) ("W]e readily enter into those high hopes of happiness which are proposed from its gratification, as well as into that exquisite distress which is feared from its disappointment.").

${ }^{11}$ West, 64 Tulane L Rev at 667 (cited in note 13). 
tions between strangers and between lovers, in which Smith argues that the operation of the mutual sympathy principle is most limited. Strangers come from different communities of sympathy and cannot know each other's expectations. The most they can expect of each other is that each will treat the other as simple objects of sympathy, that they will do each other no "positive harm. ${ }^{12}$ But they cannot subject each other to stronger claims of mutual sympathy. ${ }^{43}$ Lovers, on the other hand, are so focused on the particularity of each other that they stand uniquely outside the social realm. They were brought together by a peculiar turn of the imagination, and their interaction, as lovers, is not accessible to spectators' sympathy.

It is otherwise in communities of "habitual sympathy." In these relationships, sympathetic reasoning is particularly accurate. Relationships of habitual sympathy have two qualities: (1) habitual interaction and (2) necessity of cooperation. Habitual

42 See discussion of commutative justice expectations in note 31 .

${ }^{43}$ A number of passages tend in this direction. Smith, for instance, writes that:

Men, though naturally sympathetic, feel so little for another, with whom they have no particular connexion, in comparison of what they feel for themselves; . . . they have it so much in their power to hurt him, and may have so many temptations to do so, that if [the fundamental dictates of mutual sympathy, to do no positive harm to others] did not stand up within them in his defence,... they would, like wild beasts, be at all times ready to fly upon him; and a man would enter an assembly of men as he enters a den of lions.

Smith, Moral Sentiments at 86 (cited in note 14). This is a very guardedly optimistic assessment of human ethical conduct toward strangers. Smith denies that the prepolitical society of men is a war of all against all; the basic exercise of sympathy ensures this is not the case. Nonetheless, "[w]e expect still less sympathy from an assembly of strangers." Id at 23. The general rule of commutative justice is "the only principle by which the bulk of mankind are capable of directing their actions." Id at 162.

Our limited power of sympathy toward strangers is the reason why "the injury done by the breach of contract is the slightest possible .... One never has so great dependence on what is at the mercy or depends on the good faith of another .... The spectator can not think he has so good a ground for expectation." Smith, Lectures at 87-88 (cited in note 16). For this reason, breach of contract does not incur nearly the same degree of infamy and is not punished like injuries to person or property.

But, when we interact in communities of "habitual sympathy," we are held to a much higher standard. Smith says:

[R]elations being usually placed in situations which naturally create this habitual sympathy, it is expected that a suitable degree of affection should take place among them. We generally find that it actually does take place; we therefore naturally expect that it should; ... there is always the highest impropriety, and sometimes even a sort of impiety, in their being affected in a different manner.

Smith, Moral Sentiments at 220 . Indeed, while Smith often states that we can expect more of men and women than to just refrain from hurting others, Smith largely limits his examples to acts of beneficence among family members. See id at 80-81, 172 (discussing beneficence, and focusing on acts of beneficence between family members). For most people, he implies, our fullest expressions of virtue are limited to the realm of habitual sympathy.

"Smith, Moral Sentiments at 220 (cited in note 14). 
interaction includes living in the same household, being employed in the same location, or residing in the same neighborhood. ${ }^{45}$ Smith notes that the degree of necessity in a given habitual relationship intensifies the deliberative effort to reach mutual sympathy; in other words, the higher the cost of exiting the relationship, the greater the need for mutual sympathy within that relationship. ${ }^{46}$ Members of communities with high exit costs reach a high degree of assimilation in "sentiments, principles, and feelings." As Smith says, where one habitually associates with others,

[h] is more habituated to sympathize with them. He knows better how every thing is likely to affect them, and his sympathy with them is more precise and determinate, than it can be with the greater part of other people. It approaches nearer, in short, to what he feels for himself. ${ }^{48}$

In other words, they share the same, or substantially the same, "imaginary spectator."

Imaginative distance and community bias do not place appreciable limits on sympathetic reasoning in this context. Because every member of a community of habitual sympathy shares the same imaginary spectator, there is little imaginative distance between what $\mathrm{O}$ and $\mathrm{A}$ feel when considering the same situation. They both feel what the community's imaginary spectator would feel. Because they share the same imaginary spectator, community bias in these interactions is negligible. There is thus a high degree of uniformity and consistency in the community's expectations.

Smith's theory assumes that spouses are in a relationship of habitual sympathy. ${ }^{49}$ Spouses often begin their relationship as romantic lovers, but as romantic love leads to habitual interaction, the relationship develops into one of habitual sympathy; in other words, of friendship. Smith assumes that romantic lovers, at some point, become fully deliberative.

Thus, Smith leads us to three conclusions about expectations arising in the context of habitual sympathy. First, emotional interaction is not necessarily arbitrary, and it involves reasoned deliberation. Second, expectations are likely to be uniform within

\footnotetext{
${ }^{45}$ Id.

${ }^{46}$ Smith implies this when he states that in relationships outside the immediate family, "mutual sympathy is less necessary, ... and therefore proportionably weaker." Id.

${ }^{47}$ Id at 224.

${ }^{48}$ Id at 219.

${ }^{49}$ Id (identifying family members as objects of habitual sympathy).
} 
a community of habitual sympathy and predictable by community members. Third, members of these communities are likely to make commitments with a high degree of sensitivity to the expectations of other community members. When parties in such communities make promissory commitments, it is unlikely that these commitments will be impulsive or made without regard to particularities considered relevant by the community.

\section{JUDICIAL COMPETENCE TO EVALUATE EXPECTATIONS IN AFFECTIVE RELATIONSHIPS}

\section{A. The Argument Against Judicial Competence}

Even if parties in an affective relationship can deliberate to reach shared expectations, one party may willfully flout the expectation, or a third party, such as the executor of one party's estate, may intervene. In such a case, a party could ask a court to step in and enforce the internal expectation. Can we trust courts to intervene objectively within an affective relationship? Many commentators argue that courts cannot be trusted with such a function. According to Professors Richard Stewart and Cass Sunstein, for instance, while it may be argued that courts can identify "expectations that are 'objectively reasonable' because they are rooted in community practice and custom"50 and provide those expectations with procedural protection, "the identification of such expectations and customs is a task that may be beyond judicial competence in a pluralistic, dynamic society." structural theorists have added ammunition to the arguments against a role for courts in evaluating expectations. Fish, for instance, argues that judicial reasoning is the product of a judicial "interpretive community." Judges share similar class, race, and educational backgrounds, says Fish, and accordingly are "already and always thinking within the norms, standards, criteria of evidence, purposes, and goals of a shared enterprise."53 Judicial decision making, when operating at a nonformal level, reflects, at its root, the whim of arbitrary preferences.

Opponents of donative promise enforcement make comparable arguments. Eisenberg claims that "the world of contract is a market world, largely driven by relatively impersonal considera-

\footnotetext{
${ }^{\text {so }}$ Richard B. Stewart and Cass R. Sunstein, Public Programs and Private Rights, 95 Harv L Rev 1193, 1260 n 277 (1982).

st Id.

${ }^{52}$ Fish, Fish v. Fiss at 259-62 (cited in note 37).

${ }^{53}$ Id at 262.
} 
tions and focused on commodities and prices."54 The impersonal organs of the state have the capacity to intervene only in that realm. ${ }^{55}$ Eisenberg suggests that judges are, too institutionally removed from the variety of affective expectations that govern diverse communities and are likely to impose the subjective expectations of their own "interpretive community" on parties. ${ }^{56}$

Smith rephrases the terms of the debate. Like Stewart and and Sunstein, he believes that legal entitlements, such as a right to promise enforcement, are founded on court approval of our expectations. ${ }^{57}$ Thus, Smith argues that promises create a legal entitlement if "[t]he expectation and dependence of the promittee that he shall obtain what was promised is hear altogether reasonable, and such as an impartial spectator would readily go along with." ${ }^{58}$ However, a judicial judgment that expectations about entitlements are reasonable, as Smith's reference to the "impartial spectator" makes clear, requires judicial use of sympathetic reasoning. In other words, Smith implies that the question of whether courts are capable of intervening to enforce promissory expectations in intimate relationships is a question about the extent to which a court's reasoning about those expectations is subject to bounded sympathetic rationality.

\section{B. Overcoming Community Bias: Promising as a Signaling Device}

\section{Limits on objective legal reasoning about community expectations.}

Smith's analysis shows that the ability of judges to evaluate expectations within communities of habitual sympathy is limited by community bias. While there may be internal consistency to a community's norms of propriety, the norms of each community may differ arbitrarily from others. This limits an outsider's ability to reason sympathetically about other communities' norms.

This barrier is not, however, insurmountable. Expectations, to the extent that they are derived from habitual sympathy, arise in response to habitual interaction. Every outside observer has experienced habitual interaction and so bounded rationality is

${ }^{54}$ Eisenberg, $85 \mathrm{Cal} \mathrm{L} \mathrm{Rev} \mathrm{at} 847$ (cited in note 10).

ss Id.

${ }^{56}$ Eisenberg, $47 \mathrm{U}$ Chi L Rev at 6 (cited in note 9) ("[W]hat constitutes ingratitude and improvidence is very difficult to determine, particularly in the context of the intimate relationships that often give rise to donative promises, and this difficulty would add substantially to the problem of administration.").

${ }^{57}$ See Smith, Lectures at 87 (cited in note 16 ).

${ }^{s 8}$ Id. 
not a factor. Moreover, imaginative distance and community bias are not absolute limitations. In cases involving habitual interaction, the mutual sympathy principle is fully realizable. All human beings retain a passionate attachment to its realization and are offended by its violation. ${ }^{59}$ Because this passion is an essential attribute of sociability, its occurrence is universal; the passion does not vary across communities and so community bias is not a factor. Moreover, human beings are interested in mutual sympathy in general. Where A refuses to treat B as an object of sympathy, $A$ offends O's mutual sympathy expectation in nearly the same degree as he offends B's expectation. Imaginative distance is not a factor. ${ }^{60}$

However, $\mathrm{O}$ does remain limited by community bias and distance in his ability to sympathetically enter into a particular, community-specific expectation that holds between $A$ and $B$, since such expectations are shaped by variations among community imaginary spectators. But O is capable of "entering into" A's and B's general mutual sympathy expectation. To see how this works, consider the following nonlegal scenario. $\mathrm{O}$ is a member of Messy Community, a living group of six messy people. $\mathrm{O}$ has a penchant for leaving his dirty dishes around the house for days at a time. A and $\mathrm{B}$ are members of Neat Community, also a living group of six people. In this community, five people are neat but one is a slob. The imaginary spectator shared by Neat Community has expectations about group neatness skewed toward the neat end of the cleanliness continuum. Thus, leaving dishes out, as $\mathrm{O}$ does, is unacceptable in the Neat Community. B is cognizant of the norm of neatness in the Neat Community, but out of a mysterious maliciousness, he willfully and consistently violates this norm by refusing to clean his dishes and by displaying food-encrusted plates prominently throughout the house. Fed up, A calls for B's expulsion. A's motivation is two-fold. It is based on an evaluation that $B$ is not acting properly neat and on a disappointed mutual sympathy expectation. $O$ cannot enter into the first component of A's motivation. Because O's neatness expectations have been shaped in a different community, his objective assessment of this component is constrained by the bias of the Messy Community. Moreover, B's violation of neatness norms is not an offense against O's particular neatness expectations; B has not offended his neatness expectations. O's assessment is therefore distorted by imaginative distance. But O's assessment of the second component is nei-

\footnotetext{
${ }^{59}$ See text accompanying notes 29-31.

${ }^{60}$ See note 31.
} 
ther constrained by community bias nor by imaginative distance. He has just as much of an expectation that mutual sympathy will hold between A and B as A does. Thus, he can sympathetically enter into the second component.

There is, however, an external limitation on O's ability to enter into A's disappointed habitual sympathy expectation. B's acts will not disappoint $O$ 's mutual sympathy expectations unless $O$ is reliably informed about the differing norm of neatness that governs Neat Community. For O to enter into A's desire to expel B, Neat Community must employ a signaling device or convention that informs outsiders of its internal norms. Where such a device exists and is used and understood across communities of sympathy, sympathetic reasoning can be used objectively by outsiders to evaluate habitual sympathy expectations. Accordingly, to protect expectations about norms of generosity and gift-giving in habitual sympathy relationships, courts must be able to identify, with low decision costs, a signaling convention for such expectations.

2. Promising: Lifting the veil on community expectations.

Promising itself is such a convention. Then-Professor Charles Fried notes the conventional nature of promising. He writes that "[p]romising . . . is a very general convention ... [with] a very general purpose under which we may bring an infinite set of particular purposes. ${ }^{\prime 61}$ Fried interprets the purposes of the promising convention in a Kantian fashion. Promising exists because "[i]n order that I be as free as possible, that my will have the greatest possible range consistent with the similar will of others, it is necessary that there be a way in which I may commit myself."62 Promising creates moral obligation because it is "an expression of the principle of liberty-the will binding itself, to use Kantian language, rather than being bound by the norms of the collectivity. ${ }^{963}$

Smith's interpretation of the promising convention is different. The purpose of the convention depends on the context in which it is used. In stranger-stranger interactions, promising extends the realm of mutual sympathy. As noted above, strangers have very little natural sense of each other's expectations, beyond the fundamental expectation that neither will neglect to consider the other an object of sympathy. Thus, their expectations of each other are limited to an expectation that each will not cause the

\footnotetext{
${ }^{61}$ Charles Fried, Contract as Promise 13 (Harvard 1981).

${ }^{62}$ Id.

${ }^{63}$ Id at 19.
} 
other positive harm. ${ }^{64}$ Promising forges new links of mutual sympathy; it creates shared expectations in the performance of an exchange, or a service, or any other act; it establishes that in the one sliver of interaction governed by the promise, both parties can have the shared "sentiments, principles, and feelings" ${ }^{\text {"65 }}$ that normally govern only in relationships of habitual sympathy. By creating this sympathy, a promise sends an objective signal to outsiders about the new expectations that govern the relationship between promisor and promisee.

In interactions between community members, however, promising takes on a different aspect. There, the bonds of mutual sympathy are already extensive. It may already be understood among community members that certain acts of beneficence or mutual support are expected in certain situations due to the general closeness of sentiments and principles among members of the community. ${ }^{66}$ Each actor within the community performs these expected acts with a high degree of sensitivity toward community expectations and toward particularities considered morally relevant within the community. But, of course, outsiders are prevented by community bias from evaluating whether mutual sympathy expectations within the community have been violated. Thus, promising in this context does not so much forge new links of mutual sympathy, or create new expectations, but rather signals to outsiders when a mutual sympathy expectation exists and gives outsiders an objective ground for intervening. ${ }^{67}$

To illustrate the concept of the promise as a signal, imagine again a community governed by a norm of neatness. According to this norm, each member must take responsibility once a month for cleaning the house. There is no written rule or contract that this will be done; it is an informal expectation confirmed by habit. $B$ is aware of this expectation, but he has not always abided by it. Regretting his past failure to meet the community norm, B promises in writing that he will give his housemates money to pay for once-a-month cleaning service. B later breaks the promise and is thrown out of the house.

The promise, in this case, does not forge new expectations between $B$ and the rest of his house, $B$ and his housemates share

${ }^{64}$ See note 31.

${ }^{6}$ Smith, Moral Sentiments at 224 (cited at note 14).

${ }^{66}$ See text accompanying notes $44-48$.

${ }^{6}$ See P.S. Atiyah, Promises, Morals and Law 188 (Oxford 1981) ("[M]any forms of ritualistic promising appear to have as one of their primary purposes the desirability of making it as difficult as possible for a promisor subsequently to deny the existence of a prior obligation which was confirmed by the promise."). 
the same clear expectation about cleaning; B just irresponsibly, or perhaps maliciously, fails to comply. Whatever purpose the promise may serve between the roommates, it also serves to identify to outsiders the expectations that governed B's relationship with the house. The roommates may use B's promise to justify his expulsion. By promising, $\mathrm{B}$ has limited his ability to gain the sympathy of outsiders.

The differing uses of the promising convention in stranger and community interactions shape what courts will identify as an enforceable promise in each context. In stranger interactions, where gaps in mutual sympathy must be bridged, a promise not only signals to spectators that an enforceable commitment has been made but also forges a bond of mutual sympathy by impressing on the promisee the promisor's intent and by reasonably ensuring a firm expectation on the part of the promisee. In these cases the promise must be accompanied by significant formality. Language, and not habitual interaction and assimilation to a common imaginary spectator, is the only link that overcomes the distortions of imaginative distance and community bias. Yet, says Smith, "Language at all times must be somewhat ambiguous," which "must render it very difficult to conclude with exactness the intention of the contracting parties, and determine whether it was their inclination to produce a reasonable expectation or only to signify a design which they had at that time of acting." other words, language is too fundamentally ambiguous to bridge our imaginative separateness.

Accordingly, says Smith, the first binding contracts were those that employed formality, such as the stipulatio of Roman law, which was "conceived in a certain set form of words," contract in which one part had been performed ${ }^{70}$ or a promise accompanied by an oath, ${ }^{71}$ or a promise whose form was prescribed by long-standing commercial custom, ${ }^{72}$ or promises supported by a recognizance. ${ }^{73}$ The bargain theory of consideration, which at the time of Smith's writing had not been developed, serves as such a formality. ${ }^{74}$

Where promises occur in the context of habitual sympathy, however, the ambiguity of language is less of a barrier to mutual

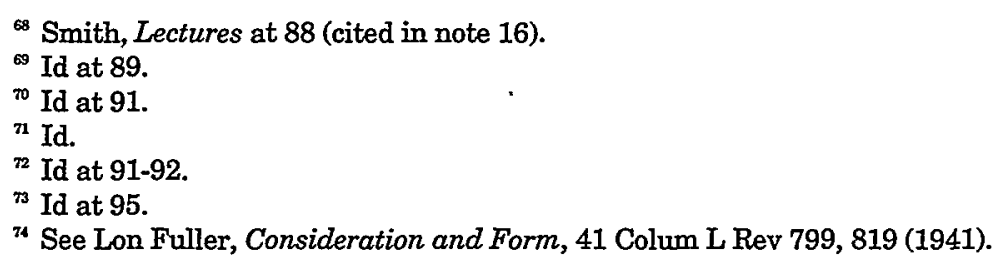


sympathy, and less formality is required. Thus, says Smith, in a permutation of the developing common law doctrine of consideration:

[I]f a father [gratuitously] promised a portion with his daughter, his being her father was a justa causa. If an uncle promised to give a portion with his niece, this was sustained also. . . . But if a stranger promised a portion this was not sustained, nor others of this sort. ${ }^{75}$

In these cases, common law courts interpreted the relationship between father and daughter, or uncle and niece, as the necessary formality. Smith's analysis shows that a simple verbal promise, plus the relationship, is all that is needed to make the promise enforceable. No additional formality is necessary. Habitual sympathy can fill the role played by ceremony in stranger cases, creating a harmony of expectation and cementing bonds of mutual sympathy. The promise, shorn of ceremony, serves its simplest function-to signal to community-biased outsiders that an expectation of mutual sympathy governs the interaction.

Smith offers a general framework for distinguishing between enforceable and unenforceable donative promises. Donative promises made in relationships of habitual sympathy should be enforceable, even in the absence of formality. But promises outside these relationships require a bargain, or some other formality, to become binding.

\section{Administering Smith's Regime of Donative Promise Enforcement}

Smith's framework is susceptible to two practical objections: (1) that courts may not be able to identify reliably informal promises in habitual sympathy contexts, and (2) that judicial

\footnotetext{
${ }^{75}$ Smith, Lectures at 95 (cited in note 16). Smith's contemporary Lord Mansfield would likely have advocated this approach. See Hawkes $v$ Saunders, 1 Cowpr 289, 98 Eng Rep 1091,1091 (KB 1782) (opinion by Mansfield) ("Where a man is under a moral obligation ... and promises, the honesty and rectitude of the thing is a consideration."), cited in Kessler, Gilmore, and Kronman, eds, Contracts: Cases and Material at 510 (cited in note 1). The rule Mansfield articulated in Hawkes, taken to its logical conclusion, supported enforcement of gratuitous promises in relationships of love and friendship. For more on Mansfield and moral consideration, see W.S. Holdsworth, The Modern History of the Doctrine of Consideration, 2 BU L Rev 174, 186-95 (1922) (discussing Lord Mansfield's attempt to reformulate the doctrine of consideration to include moral consideration); Teeven, A History of the Anglo-American Common Law of Contract at 228 (cited in note 1) (noting that Mansfield favorably cited the sixteenth century contract case Dutton v Pool [86 Eng Rep 205 (KB 1678)], in which the motives of love and affection and morality were relevant in finding sufficient consideration in family transactions).
} 
identification of communities of habitual sympathy would be administratively unworkable.

\section{Identifying informal, unrelied-on promises.}

While Smith establishes that informal oral promises are sufficient to create expectations in habitual sympathy communities, outsiders might still have difficulty identifying whether a promise has been made. Even if formality is not needed to cement a unity of expectations between promisor and promisee, is not formality still necessary to make promising an efficient signaling device to outsiders?

Perhaps not. Fried notes that promising itself is a kind of formality; to speak of "informal" promises is to signify relative informality. Fried observes that even an "informal" promise may be subjected to the well established, and administratively familiar, legal requirements of offer and acceptance, rather than such super-formality as a bargain or seal or "set form of words."76 As Fried explains, the doctrine of offer and acceptance considered alone requires that the promisor directly communicate objective intention to a particular promisee and that the promisee objectively accept the promise. ${ }^{77}$ The communication of the offer and the acceptance need take no set form, other than to convey objective intent to bind oneself and to accept. ${ }^{78}$ Courts have long experience with applying these basic contract law standards.

\footnotetext{
${ }^{76}$ Fried, Contract as Promise at 40 (cited in note 61) (noting that "the intricacies of offer and acceptance in contract law" are among the first, most fundamental, technical bodies of law introduced to law students). The First Restatement provides the classic formulation of the "mutual assent" requirement for contract formation:

If from a promise, or manifestation of intention, or from the circumstances existing at the time, the person to whom the promise or manifestation is addressed knows or has reason to know that the person making it does not intend it as an expression of his fixed purpose until he has given a further expression of assent, he has not made an offer.

Restatement of Contracts $\S 25$ (ALI 1932). The Second Restatement preserves this formulation, but changes the emphasis from promise to bargain. See Restatement (Second) of Contracts \& 24 (ALI 1979). Fashioning offer and acceptance for donative promises would require a revival of the First Restatements promise-centered emphasis.

${ }^{77}$ Fried, Contract as Promise at 40-43, 142 n 3 (cited in note 61) (noting that under contract doctrine an offer must be communicated to a particular person and must be accepted to become binding). See also Restatement of Contracts $\S 230$ (the test for offer and acceptance is objective, not subjective); id $\S 36$-37 (offer is rejected when offeror can infer rejection from words or conduct of offeree); Restatement (Second) of Contracts $\S 38$ (offeree's power of acceptance terminated by rejection); id \$§ 58-59 (an acceptance must be unconditional and unqualified).

${ }^{78}$ See Fried, Contract as Promise at $142 \mathrm{n} 4$ (cited in note 61) ("What is required is the promisee's intentional acceptance, intention being objectively understood.").
} 
Fried and Smith make the point that courts may structure a signaling promise in any number of ways short of the traditional common law formalities of bargain, exchange, part performance, seal, or writing. These formalities serve largely to cement expectations between parties, by relying on ceremony or other means of transcending the give-and-take of simple language. ${ }^{79}$ But when a promise is made against a backdrop of habitual sympathy, this heightened formality is superfluous; accordingly, only a de minimis degree of formality-relative informality -is necessary to make a promise function efficiently as a signaling device.

\section{Identifying communities of habitual sympathy.}

The deeper problem, perhaps, is the administrative feasibility of identifying habitual sympathy relationships. How much and what kind of interaction is necessary to create harmony of expectations? Won't the distinction between habitual and nonhabitual relationships prompt parties to engage in messy and unwieldy disputes about the duration and intimacy of their relationship?

The claim that courts are not capable of sifting between affective and stranger relationships is belied by modern common law. Some courts have maintained such a distinction in dealing with liability for third-party emotional distress. In Dillon $v$ Legg, ${ }^{80}$ the defendant ran over a small child with his car as the child crossed the street. The accident occurred in plain view of the child's mother and sister. ${ }^{81}$ The California Supreme Court imposed liability for emotional distress but declared that liability for third party emotional harm must be predicated on a close relationship, "as contrasted with an absence of any relationship or the presence of only a distant relationship" between the person directly harmed and the third party emotionally injured. ${ }^{82} \mathrm{Al}-$ though some commentators and courts have questioned whether this distinction is too amorphous to be administrable, ${ }^{83}$ California

${ }^{79}$ See Smith, Lectures at 88 (cited in note 16).

\$o $68 \mathrm{Cal} 2 \mathrm{~d} 728,441$ P2d 912 (1968).

${ }^{81} 441 \mathrm{P} 2 \mathrm{~d}$ at 914-15.

2 Id at 920. The Dillon approach has been tentatively adopted in a few jurisdictions outside California. See, for example, Maldonado v National Acme Co, 73 F3d 642, 644-45 (6th Cir 1996) (noting that Michigan's test for negligent infliction of emotional distress includes a "close relation"); Ledford v Delta Airlines, 658 F Supp 540, 542 (S D Fla 1987) (noting Florida's use of the close relationship requirement).

${ }^{3}$ See, for example, Tobin $v$ Grossman, 24 NY2d 609, 249 NE2d 419, 422-24 (1969) (claiming that the Dillon approach would radically expand tort liability beyond courts' administrative capacity); Amodio v Cunningham, 182 Conn 80, 438 A2d 6, 9 (1980) (agreeing with the Tobin court that "there appears to be no rational way to limit the scope 
courts have largely confined recovery under Dillon to members of the nuclear family. ${ }^{84}$ New Jersey courts have extended Dillon's "close relation" prong to unmarried cohabitants, if they can "prove on a case-by-case basis that they enjoy a steadfast relationship that is equivalent to a legal marriage." ${ }^{85}$

The Dillon distinction closely approximates Smith's concept of habitual sympathy. According to Smith's analysis, interactions that are both habitual and necessary are those most likely to generate uniformity of expectations. As Smith explains, "the members of his own family, those who usually live in the same house with him, his parents, his children, his brothers and sisters" compose one set of core habitual sympathy relationships. ${ }^{86}$ The immediate family is a core habitual sympathy relationship, because in relationships outside the immediate family "mutual sympathy is less necessary, . . . and therefore proportionably weaker." ${ }^{87}$ Smith implies that mutual sympathy is more necessary within family relationships because the psychological and material costs of exiting the relationship are particularly high. The custom and formality that create and define relationships between spouses and between parents and children contribute to the high cost of exit. However, Smith also identifies long-time cohabitation as an essential component of habitual sympathy. Thus, Smith implies that long-time cohabitation creates its own necessity of mutual sympathy and gives rise to substantial exit costs even if the cohabitation is informal. Relationships of habit-

of liability except by establishing arbitrary distinctions"); D'Ambra $v$ United States, 338 A2d 524, 530 (RI 1975) (finding difficulty in drawing "reasonable parameters to the field of legal liability" when using the Dillon test). See generally Richard N. Pearson, Liability to Bystanders for Negligently Inflicting Emotional Harm: A Comment on the Nature of Arbitrary Rules, 34 U Fla L Rev 477, 516 (1982) (arguing that recovery for emotional distress should be limited to the zone-of-danger test, which permits those who were at risk of physical injury to recover for emotional distress); J. Mark Appleberry, Comment, Negligent Infliction of Emotional Distress: A Focus on Relationships, 21 Am J L \& Med 301, 312 (1995) ("The [Dillon] test is literally too flexible, and courts apply the test in an unprincipled manner.").

${ }^{8}$ See, for example, Elden $v$ Sheldon, $46 \mathrm{Cal} 3 \mathrm{~d}$ 267, $758 \mathrm{P} 2 \mathrm{~d} 582,587-88$ (1988) (denying claims for negligent infliction of emotional distress to an unmarried cohabitant, and limiting the "close relation" prong of the Dillon test to the "nuclear family"). The Dillon rule is not universally followed outside of California. See, for example, Rickey $v$ Chicago Transit Authority, $98 \mathrm{Ml}$ 2d 546, 457 NE2d 1, 5 (1983) (rejecting Dillon approach in favor of the older zone-of-danger test for third-party psychological harm). See also Hatlestad $v$ Consolidated Rail Corp, 75 Ohio App 3d 184, 598 NE2d 1302, 1306-07 (1991) (recognizing the zone-of-danger test); Bovsun $v$ Sanperi, 61 NY2d 219, 461 NE2d 843, 848 (1984) (same); Stadler v Cross, 295 NW2d 552, 553 (Minn 1980) (same); Vaillancourt $v$ Medical Center Hospital of Vermont, 139 Vt 138, 425 A2d 92, 95 (1980) (same).

${ }^{85}$ Dunphy v Gregor, 136 NJ 99, 642 A2d 372, 377-80 (1994).

${ }^{86}$ Smith, Moral Sentiments at 219 (cited in note 14).

${ }^{87}$ Id at 220 . 
ual sympathy, then, include relationships between cohabitants as well as immediate family members.

Accordingly, a Smithian donative promising regime employing a Dillon "close relationship" prong would create a per se rule that informal and formal donative promises between immediate family members and between long-time cohabitants will be enforced. Extending enforcement to cohabitants would obviously require that courts consider cohabitant relationships on a case-bycase basis. Yet, Smith's analysis, which claims that length of habitual interaction is sufficient to overcome community bias and imaginative distance, simplifies this case-by-case inquiry by reducing the relevant factors to one: the length of cohabitation. Uncertainty remains, of course. While twenty-year cohabitants may be considered a fully deliberative community of habitual sympathy, seven-year cohabitants pose a close question. Nonetheless, Smith's approach, using length of cohabitation as a proxy for closeness of relationships, creates fewer administrative costs than the closeness inquiry already undertaken by Dillon-influenced courts.

Admittedly, a regime that limits enforcement of donative promises to immediate family and long-time cohabitants may be underinclusive. Strong habitual sympathy may exist between those who are neither immediate family nor cohabitants-for instance, long-time friends or co-workers who spend a great degree of time together but have separate residences. Yet, in cases where habitual interaction cannot be inferred from the existence of a formal family relationship or a cohabitant relationship, the costs of habitual sympathy identification are likely too high. While critics might charge that this concession to administrative costs makes Smith's rule arbitrary, common law line-drawing between close and nonclose relationships has consistently refused to draw the line beyond cohabitants. This is true not only in the Dillon line of cases, but also in modern moral consideration cases, which have sporadically found cohabitation to be "moral consideration," but have not extended this same recognition to noncohabiting friends. ${ }^{88}$ Against the backdrop of common law traditions, draw-

\footnotetext{
See, for example, Dunphy, 642 A2d at 379 (finding that a cohabitation may suffice to create a judicially recognized "close relationship"); Auleta v Bernadin, 113 Misc 2d 526, 449 NYS2d 395, 398-99 (1982) (upholding support agreement based on past cohabitation); Latham $v$ Latham, 274 Or 421, 547 P2d 144, 147 (1976) (finding that cohabitation provided consideration for a promise to give plaintiff one-half of all of promisor's property, both real and personal), affd on other grounds, 281 Or 303, 574 P2d 644 (1978). By contrast, modern treatises discussing moral consideration mention no cases in which friendship has sufficed to create a binding obligation. See Lord, 3 Williston on Contracts $\$ 7: 16$ at 323-26 (cited in note 2) (discussing love and affection as "good" or "meritorious" consid-
} 
ing a line between cohabitants and noncohabitants appears far less arbitrary.

D. Applying Smith's Approach

Consider, now, how Smith's theory of donative promise enforcement allows resolution of the three potentially confusing cases mentioned at the beginning of this Comment:

1. Rich Aunt Tillie, a kindly soul, is prodded by her grasping sister to give nephew Charley $\$ 1,000$ on his fifth birthday. Tillie says to Charley, while her sister watches, "Charley, how would you like it if I were to give you $\$ 1,000$ for your fifth birthday?” Charley replies, "Boy, would I ever!" And Tillie responds, "Well, then, you can count on it, no matter what, when you turn five." Charley, however, subsequently sets fire to Tillie's favorite couch before his fifth birthday, and she loses her gift-giving enthusiasm. When Charley's fifth birthday rolls around, Tillie reneges.

Under Smith's rule, Tillie's promise is unenforceable. There is an oral offer and acceptance. But Tillie is not immediate family and has not lived with Charley, and therefore is not in a judicially recognized relationship of habitual sympathy. Smith's rule assumes that even though Tillie and Charley are related by blood, Tillie's promise to Charley is not likely to be fully deliberative.

2. Jane and Susan are a long-time lesbian couple who have lived with each other for fifteen years. Jane, terminally ill, promises Susan that when she dies Susan may have all that Jane owns. Jane dies shortly thereafter. Jane's estranged family become executors of her estate and refuse to honor Jane's promise. Susan sues for enforcement.

Under Smith's rule, Jane's promise is enforceable, since Jane and Susan's long-time cohabitation seems reasonably likely to produce a core habitual sympathy relationship. Remember that under Smith's analysis, this is not a case of bounded commonality. Smith argues that when romantic lovers habitually interact long enough, their relationship is transformed into a relationship 
of habitual sympathy. Since long-time cohabitants are in a relationship of habitual sympathy, ${ }^{89}$ there is no reason to believe that Jane and Susan's relationship is nondeliberative. Note, too, that this example suggests that extension of per se donative promise enforcement to spouses is overinclusive. Some spouses may marry impulsively while they are still romantic lovers and long before habitual sympathy has developed between them. Yet, to the extent that the formality and attendant exit costs of marital relations make mutual sympathy more necessary, this overinclusiveness is mitigated.

3. Bill, Bob, and Barney are brothers who were separated in their early teens and placed in separate foster homes. Bill, thirty years later, wins the lottery and wants to share his fortune with his long-lost brothers. Thanks to an edition of the popular television program Unsolved Mysteries, Bill receives the tip he needs to find his brothers, and in an unrehearsed, televised reunion, he promises each brother $\$ 1$ million. Before he pays them, however, he learns that Bob and Barney are both rather nasty characters. Disappointed, he refuses to honor his promises and is sued.

According to Smith, a blood relationship alone does not produce habitual sympathy. The brothers' long separation destroys their bonds of habitual sympathy. As Smith says, even though long-lost brothers might imagine that, on the basis of blood alone, a habitual sympathy will spontaneously develop between them, "[t]ime and experience . . . too frequently deceive them. Upon a more familiar acquaintance, they frequently discover in one another habits, humours, and inclinations ... to which, from want of habitual sympathy, ... they cannot now easily accommodate themselves. ${ }^{390}$ Habitual sympathy requires habitual interaction, not merely a blood relationship. It is only through continuous, intimate, and necessary association that expectations are assimilated, and that, therefore, gratuitous promises can be fully deliberative. Accordingly, the brothers' foster families, and not their blood relations, would count as "immediate family" in a Smithian donative promising regime.

* Smith, Moral Sentiments at 219 (cited in note 14).

${ }^{\infty}$ Id at 221. 


\section{THE ETHICAL BASIS FOR ENFORCING INFORMAL DONATIVE PROMISES}

Smith's theory of sympathetic reasoning establishes that commitments within immediate family or among long-time cohabitants are likely to be deliberative; promising, a signaling device, permits objective judicial evaluation of expectations that arise within these relationships. Enforcing expectations about generosity within close communities is therefore administratively feasible. But, even so, some critics claim that enforcing informal donative promises in these "moral consideration" contexts will impose substantial ethical costs.

Smith's rule of donative promising faces two kinds of ethical objections. The first is based on the principle that we should treat others as ends, and not as means. By promising, we invite trust and cooperation; we bind ourselves so that others may depend on us and aid us. Breaking a promise, therefore, uses the promisee as a means. As a result, ethical considerations dictate that promises outside of habitual relationships should not be limited by formality. ${ }^{91}$

For Smith, the boundaries of mutual sympathy define the realm of the ethical. The use of sympathy is the treatment of another as an end. But, in situations where our sympathetic reasoning is most limited, we are bounded in our capacity to treat others as ends. Where we interact as strangers, imaginative distance and community bias work most strongly. We are uncertain whether our acts will cause strangers psychological harm, and strangers have little expectation that we will act with sensitivity to psychological harm. In this context, mutual sympathy makes weak claims on us. In close communities, however, imaginative distance and community bias fall away; there, the mutual sympathy principle is stronger and greater ethical demands are placed upon us-demands of mutual support, generosity, and general sensitivity to psychological harms. This bifurcated ethical regime is the only ethical regime that can reasonably govern most men and women, muddled as they are by their separation into communities and individuals. ${ }^{92}$

${ }^{91}$ See Fried, Contract as Promise at 17 (cited in note 61) ("By virtue of the basic Kantian principles of trust and respect, it is wrong to invoke [the promising] convention in order to make a promise, and then to break it.").

${ }^{92}$ See notes $42-48$ and accompanying text. Smith, it should be noted, does not deny that human beings are capable of meeting more rigorous ethical standards. Following the Stoics, Smith distinguishes between the ethics of the many and those of the sage, or "wise man." See Smith, Moral Sentiments at 247-48 (cited in note 14). See also Cicero, On Duties at 105 (cited in note 19) ("The duties that I discuss . . . are, then, those what the Stoics call 
The second ethical charge is made by the opponents of donative promise enforcement. Legal intervention into donative promises, they say, devalues affective commitments. Eisenberg presents a representative example of this argument. He suggests that in an enforceability regime, it "could never be clear to the promisee, or even to the promisor, whether a donative promise that was made in a spirit of love, friendship, affection, or the like, was ... performed to discharge a legal obligation or avoid a lawsuit." As a result, "love, affection, friendship, gratitude, and comradeship" would become impoverished. ${ }^{94}$

Yet, the assimilation of expectations in habitual relationships prevents uncertainty about the motivation behind promissory performance. When promises are performed out of a fear of legal liability, the promisee is not likely to be misled. Eisenberg implies a deeper claim, however. Legal compulsion, he implies, strikes at the very essence of an affective commitment's value, and not just at the clarity of intent behind an affective commitment. ${ }^{95}$ This charge is based on the prior assumption that promissory entitlements are derived from impersonal concerns-satisfaction of self-interest, making a profit. These concerns are the lowest common denominator in human interaction, troublesome background activity that must be regulated to maximize the good of the whole. But promises based on affective considerations represent our nobler aspirations. The law should reflect their special nature, and does so by placing the world of affective expectations beyond legal coercion. Legal intrusion into this realm would de-

'middle.' They are shared, and widely accessible.... But the duty that the same men call 'right . . . cannot belong to anyone except the wise man."). The ethics of the many are determined by a kind of reflexive sympathy-sympathetic deliberation that is guided by accidental circumstances, such as habitual interaction. But the sage engages in a deliberative sympathy. Smith, Moral Sentiments at 247 . The sage actively seeks out circumstances and people outside his circles of habitual sympathy, both to hone his sensitivity to a broader range of morally relevant particularities as well as to reduce the distortions of his judgment created by imaginative distance and community bias. See id at 154 (urging those who seek virtue to "[]ive with strangers"). The imaginary spectator of the sage is a universalization drawn from a wider consideration of particular evaluative judgments, and so approaches more universal ethical norms.

But the norms perceived by the sage cannot govern most men and women. See id at 233 (arguing that the wise man, "like Solon, when he cannot establish the best system of laws, he will endeavour to establish the best that the people can bear"). In this Smith follows representatives of the Middle Stoa such as Cicero, who argued that the ethical rules appropriate to the Stoic sage are impractical, and unrealistic, guides for imperfect men and women. Cicero, On Duties at 106.

* Eisenberg, $85 \mathrm{Cal} \mathrm{L} \mathrm{Rev} \mathrm{at} 848$ (cited in note 10).

" Id at 847 .

${ }^{\circ}$ Id at 849 (stating that values of love and friendship are "too important to be enforced by law .... It is just because these values are usually missing from the more impoverished world of contract that the law must play a central role in that world"). 
stroy its special nature. Affective commitments would be irreparably devalued. ${ }^{96}$

In contrast, Smith argues that legal entitlements, even the enforcement of promising within the "impersonal" market, are premised first and foremost on the principle of mutual sympathy and derived from the "imaginary spectator" test, which is a form of ethical reasoning. Indeed, he notes with approval at the close of The Theory of Moral Sentiments that "Cicero in his Offices, and Aristotle in his Ethics, treat justice in the same general manner in which they treat all the other virtues." rules express ethical conclusions. Even rules protecting promissory expectations in the marketplace are not founded on utilitarian concerns. As Smith says, the law protects expectations "not so much from a concern for the general interest of society, as from a concern for that very individual who has been injured."98 Accordingly, a breach of a promise in the marketplace calls for legal intervention on ethical grounds.

For Smith, then, legal protection serves an important expressive purpose: it reinforces the idea that certain expectations are fundamentally worthy of our sympathetic attention. Formal promises to strangers are enforced because promises forge bonds of mutual sympathy, and their breach represents a failure to consider another as an object of sympathy. But promises among community members point to even stronger, more certain expectations of mutual sympathy. Thus, in the Smithian view, to afford stranger promises the ethical recognition of legal protection, without doing the same for those within a relationship of habitual sympathy, is to overvalue the former and greatly undervalue the latter. This is, in short, a very poor expressive use of the law.

\section{CONCLUSION}

In the Nicomachean Ethics, Aristotle wrote that the community should attend to the upbringing and practices of the young,

${ }^{96}$ Roberto Unger summarizes this argument nicely:

[Contract law] contrasts an ideal of private community, meant to be realized chiefly in the life of family and friendship, to the ideal of contractual freedom, addressed to the world of self-interested commerce. The social realm is pictured as rich in precisely the attributes that are thought to be almost wholly absent from the economic realm. The communal forms in which it abounds, islands of reciprocal loyalty and support, neither need much law nor are capable of tolerating it. For law in this conception is the regime of rigidly defined rights that demarcate areas for discretionary action.

Unger, 96 Harv L Rev at 622 (cited in note 12).

${ }^{n}$ Smith, Moral Sentiments at 341 (cited in note 14).

${ }^{98}$ Id at 90 . 
and that "attention by the community works through laws."99 The lawgiver "should urge people toward virtue, and exhort them to aim at what is fine."100 Thus, proper laws express what we as a political community can agree is necessary to human flourishing-flourishing measured not simply by material goods but by ethical goods, as well. Laws not only deter, or punish, or create incentives. They must instruct.

This is often assumed to be an illiberal idea. ${ }^{101}$ Smith shows that it is not. In a pluralistic political community, there is a narrow range of agreement about what constitutes ethical flourishing. Smith usefully tempers enthusiasm for expressive use of the law by sketching the limits within which judges can accurately assess diverse norms. But he reminds the skeptics that judicial reasoning is not absolutely limited in undertaking an expressive role. There are some ethical goods on which we can all agree, and, Smith argues, respecting commitments to those closest to us is one such good. Once, the common law recognized these commitments. Smith reminds us that courts, then, fashioned laws not simply to maximize utility but to foster a moral community of interdependent men and women. Enforcing donative promises is one step toward recapturing that Smithian legal world.

${ }^{9}$ Aristotle, Nicomachean Ethics at 1180a35 (cited in note 29).

${ }^{100}$ Id at 1180a10.

${ }^{102}$ See H.L.A. Hart, Law, Liberty and Morality 5-6 (Stanford 1963) (arguing that a liberal state can only prevent individuals from inflicting harm on others, but cannot use legal coercion to enforce morality). See generally Stephen P. Garvey, Can Shaming Punishments Educate?, 65 U Chi L Rev 733, 772-75 (1998) (discussing objections to the theory that punishment should educate). 


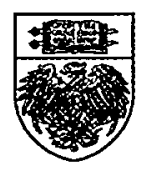

